\title{
KONSEP PERCAYA DIRI DALAM AL QUR'AN SURAT ALI IMRAN AYAT 139
}

\section{Aya Mamlu'ah ${ }^{1}$}

\section{IAI Sunan Giri Bojonegoro}

\author{
ayamamluah@gmail.com
}

\begin{abstract}
Abstrak
Al-Qur'an, as kalamullah or the miracle of Islam revealed by Allah to the Prophet Muhammad for all people. Islamic teachings, are a blessing for the entire universe, rahmatan lilalamin. In essence, the Qur'an has spoken of all human beings which contain basic principles, in the Qur'an there are many concept of confidence such as optimism in facing life's various obstacles; Always try and pray in all deeds; Put your trust in Allah for everything that happens; Never stop expecting His grace and pleasure; Confident of the capabilities possessed and based on praying in doing an action; Always grateful for everything God has given us; Practicing both of these qualities in studying.
\end{abstract}

Keyword: Konsep Percaya diri, Al Qur'an

\section{Pendahuluan}

Kepercayaan diri merupakan aspek kepribadian manusia yang berfungsi penting untuk mengaktualisasikan potensi yang dimilikinya. Tanpa adanya kepercayaan diri maka banyak masalah akan timbul pada manusia. Dengan adanya rasa percaya diri maka seseorang akan mudah bergaul. Menghadapi orang yang lebih tua, lebih pandai maupun lebih kaya, mereka tidak malu mau pun canggung. Mereka akan berani menampakkan dirinya secara apa adanya, tanpa menonjol-nonjolkan kelebihan serta menutup-nutupi kekurangan. Ini disebabkan orang-orang yang percaya diri telah benar-benar memahami dan mempercayai kondisi dirinya, sehingga telah bisa menerima keadaan dirinya apa adanya.

Teori-teori psikologi banyak mengungkap tentang fenomena ini berdasarkan pandangan mereka terhadap kepribadian manusia. Percaya diri muncul dari konsep dan citra diri yang dimiliki oleh setiap orang. Teori kepribadian eksistensialis mengungkapkan bahwa seperti apa manusia membayangkan maka seperti itulah ia. Teori kepribadian behavioris menegaskan bahwa manusia adalah hasil dari pengaruh-pengaruh di sekelilingnnya. Teori keperibadian psikoanalisa menjelaskan bahwa setiap manusia adalah totalitas dari mana ia

\footnotetext{
${ }^{1}$ Dosen IAI Sunan Giri Bojonegoro
} 
bergantung berkembang sendiri. Dan teori aktualisasi diri menjelaskan bahwa manusia adalah realisasi dari potensinya yang terbesar. Percaya diri muncul dari bagaimana seseorang memandang dirinya. ${ }^{2}$

Al-Qur'an, sebagai kalamullah atau mukjizatul Islam yang diturunkan Allah kepada Nabi Muhammad SAW untuk seluruh manusia. Ajaran Islam, merupakan rahmat bagi seluruh alam semesta, rahmatan lilalamin. Pada hakikatnya, al-Qur'an telah berbicara tentang seluruh persoalan manusia yang berupa prinsip-prinsip dasar.

Al-Qur'an berbicara kepada akal dan perasaaan manusia; mengajar mereka tentang aqidah tauhid; membersihkan jiwa mereka dengan berbagai praktek ibadah; memberi mereka petunjuk untuk kebaikan dan kepentingannya, baik dalam kehidupan individu maupun sosial; menunjukkan kepada mereka jalan terbaik, guna mewujudkan jati dirinya, mengembangkan kepribadiannya dan meningkatkan dirinya menuju kesempurnaan insani, sehingga mampu mewujudkan kebahagiaan bagi dirinya, di dunia dan akhirat. Dalam tulisan ini akan dikupas tentang konsep percaya diri yang tertuang dalam al Qur'an QS. Ali Imran: 139.

\section{PEMBAHASAN}

\section{A. Konsep Percaya Diri}

Menurut ahli psikologi Sigmund Freud, kepercayaan diri adalah satu tingkatan rasa sugesti tertentu yang berkembang dalam diri seseorang sehingga merasa yakin dalam berbuat sesuatu. Menurut Thantawy dalam kamus istilah bimbingan dan konseling (2005:87), percaya diri adalah kondisi mental atau psikologis diri seseorang yang memberi keyakinan kuat pada dirinya untuk berbuat atau melakukan suatu tindakan. Menurt Lie, seseorang yang percaya diri dapat menyelesaikan tugas atau pekerjaan yang sesuai dengan tahapan perkembangan dengan baik. Merasa berharga, mempunyai keberanian, dan kemampuan untuk meningkatkan prestasinya.

Mempertimbangkan berbagai pilihan, serta membuat keputusan sendiri merupakan perilaku yang mencerminkan Percaya Diri. Menurut Lauster (2004:4), Kepercayaan diri merupakan suatu sikap atau keyakinan atas kemampuan diri sendiri

2 Fenomena tutup mulut, tidak mau berbicara yang terjadi pada mahasiswa untuk mengungkapkan pendapatnya ketika terjadi diskusi bukanlah sikap dan tindakan yang dapat memajukan keilmuan bagi dirinya. Sikap seperti ini dapat terjadi disebabkan oleh minimnya percaya diri. Karena pada dasarnya ia ingin melakukan itu akan tetapi karena tidak percaya diri maka diam saja, karena perasaan takut, cemas, minder sehingga sesudah itu, akan menyesali keadaannya yang tidak mampu berbicara dan mengungkapkan apa yang ada dibenaknya. Apalagi, ketika apa yang ingin diungkapkan tersebut ternyata disampaikan oleh orang lain maka ia langsung menyesali tindakan diam yang diambilnya. 
sehingga dalam tindakan-tindakannya tidak terlalu cemas, merasa bebas untuk melakukan hal-hal yang sesuai keinginan dan tanggung jawab atas perbuatannya. Sopan dalam berinteraksi dengan orang lain, memiliki dorongan prestasi serta dapat mengenal kelebihan dan kekurangan diri sendiri. Lauster menggambarkan bahwa orang yang mempunyai kepercayaan diri memiliki ciri-ciri tidak mementingkan diri sendiri (toleransi). Tidak membutuhkan dorongan orang lain, optimis dan gembira.

Menurut pendapat Angelis (2003:10), percaya diri berawal pada tekad diri sendiri, untuk melakukan segala yang kita inginkan dan kita butuhkan dalam hidup. Percaya diri tebina pada keyakinan diri sendiri, sehingga kita mampu mengnhadapi tantangan hidup apapun dengan berbuat sesuatu.

Menurut rahmat $(2000 ; 109)$ kepercayaan diri dapat diartikan sebagai sesuatu kepercayaan terhadap diri sendiri yang dimiliki oleh setiap orang dalam kehidupannya serta bagaimana orang tersebut memandang dirinya secara utuh dengan mengacu pada konsep diri. Jika di sederhanakan, Percara Diri itu adalah asa yang ada dalam jiwa. Penuh keyakinan dan rasa mampu untuk mewujudkan sesuatu dengan segala kemampuan yang dimiliki dan menyajikannya dengan yang terbaik. Plus prosesnya baik dan mengharap hasil yang terbaik.

Al-Qur'an sebagai rujukan pertama juga menegaskan tentang percaya diri dengan jelas dalam beberapa ayat-ayat yang mengindikasikan percaya diri seperti:

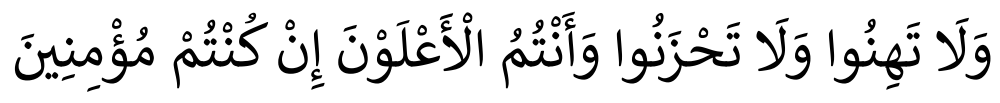

Janganlah kamu bersikap lemah, dan janganlah (pula) kamu bersedih hati, padahal kamulah orang-orang yang paling tinggi (derajatnya), jika kamu orangorang yang beriman. (Ali Imran: 139)

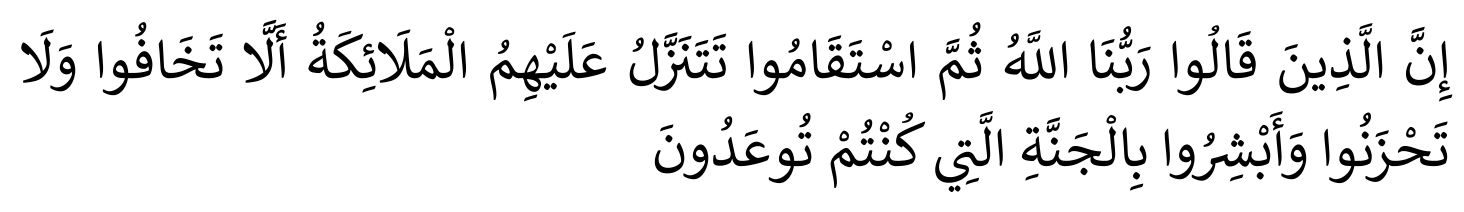

Sesungguhnya orang-orang yang mengatakan: "Tuhan kami ialah Allah" kemudian mereka meneguhkan pendirian mereka, maka malaikat akan turun kepada mereka (dengan mengatakan): "Janganlah kamu merasa takut dan janganlah kamu merasa sedih; dan bergembiralah kamu dengan (memperoleh) surga yang telah dijanjikan Allah kepadamu". (Fusshilat: 30).

Ayat-ayat di atas dapat dikategorikan dengan ayat yang berbicara tentang persoalan percaya diri karena berkaitan dengan sifat dan sikap seorang mukmin yang memiliki nilai positif terhadap dirinya dan memiliki keyakinan yang kuat. 
Dari ayat di atas nampak bahwa orang yang percaya diri dalam al-Qur'an di sebut sebagai orang yang tidak takut dan sedih serta mengalami kegelisahan adalah orang orang yang beriman dan orang-orang yang istiqomah. Banyaknya ayat-ayat lain yang menggambarkan tentang keistimewaan kedudukan manusia di muka bumi dan juga bahkan tentang keistimewaan umat Islam, yang menurut penulis merupakan ayat-ayat yang dapat dipergunakan untuk meningkatkan rasa percaya diri.

Ma'rifatun-nafsi atau mengenal diri sendiri terkenal dengan ungkapan "barang siapa yang mengenal dirinya, maka ia mengenal Tuhannya", Dapat disejajarkan dengan konsep diri, self concept yaitu bagaimana seseorang memandang dirinya sendiri. Khusnudzon atau prasangka yang baik juga dapat disejajarkan dengan berpikir positif. Kata-kata yang terus beriringan dalam al-Quran yaitu iman dan amal merupakan penegasan dari harus adanya keyakinan dan tindakan. Untuk menyikapi semua tindakan-tindakan dan hasil yang diperoleh atas semua usahanya Islam memberikan konsep lain seperti tawakal, syukr dan muhasabah yang harus diamalkan dalam kehidupan sehari-hari. Akumulasi konsep-konsep tersebut jika diteliti secara berkesinambungan akan menimbulkan dan mengisyaratkan adanya konsep percaya diri yang terungkap dalam al-Qur'an.

Dalam ayat lain Allah memberikan gambaran tentang putus asa QS; Yusuf: 87

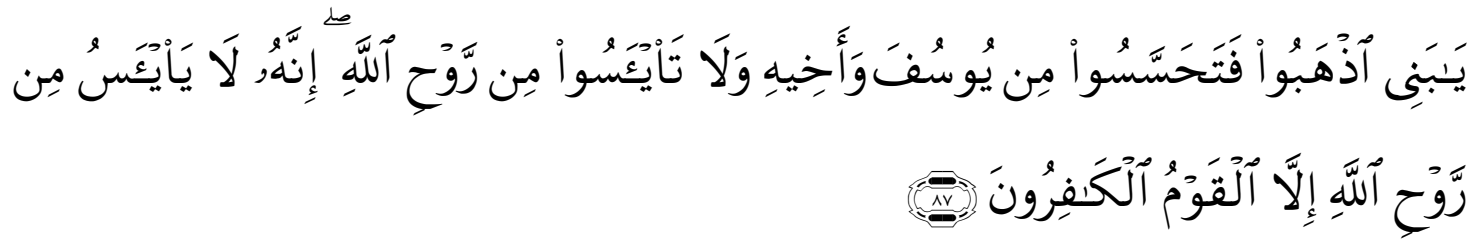

"Hai anak-anakku, Pergilah kamu, Maka carilah berita tentang Yusuf dan saudaranya dan jangan kamu berputus asa dari rahmat Allah. Sesungguhnya tiada berputus asa dari rahmat Allah, melainkan kaum yang kafir."

Allah mengisahkan Yakub tatkala menghimbau putra-putranya agar mereka pergi mencari berita tentang Yusuf dari saudaranya Benyamin. la member semangat kepada mereka agar tidak berputus asa dari rahmat Allah dan agar tetap berharap akan menemukan Yusuf dan saudaranya, karena hanya orang kafirlah yang lekas berputus asa. ${ }^{3}$

Sesungguhnya agama Islam memerintahkan kepada kita semua agar kita percaya diri dan tidak putus asa dalam mencari rahmat dan hidayah Allah SWT. Kita sebagai

\footnotetext{
${ }^{3}$ H.Salim Bahreisy dan Said B. Terjemah Singkat Tafsir Ibnu Katsir jilid IV. (Surabaya: Bina Ilmu 1998). 400
} 
manusia wajib ikhtiar kepada Allah SWT karena semua masalah pasti ada jalan keluarnya. Sebagaimana pesan Nabi Yakub As kepada anak-anaknya dalam mencari saudaranya Yusuf serta Bunyamin. Pada ayat tersebut diatas pesan nabi Yakub as bukan saja memerintahkan kepada anak-anaknya untuk terus berharap dan percaya diri serta tidak putus asa dalam mencari saudaranya, tetapi ada pesan kepada kita semua agar percaya diri dan tidak putus asa dalam mencari rahmat Allah SWT.

Kata "Rauh" dari ayat tersebut lebih dalam makna dan takaranya serta lebih banyak kandunganya, didalamnya mengandung naungan tempat beristirahat dari musibah yang mencekik dengan apa yang menghibur jiwa. ${ }^{4}$ Maka dari itu orang-orang yang beriman selalu berhubugan dengan Allah, raga dan bathin mereka selalu disirami dengan ruh Allah yang menghidupkan dan menyemangatinya. Mereka itu tidak pernah putus asa dari rahmat Allah, walaupun mereka diliputi oleh segala musibah yang menghampirinya, karena mereka dalam ketenangan kepercayaan terhadap Allah SWT.

Dari ayat diatas bahwa Yakub sebagai orang tua yang tentunya banyak memiliki pengalaman dan kesabaran juga ilmu yang tinggi. Percaya diri dan tidak putus asa bukan saja ditunjukan bagi orang tua kepada anaknya, orang yang lebih tua kepada yang lebih muda tetapi juga pesan yang disampaikan dari orang yang berilmu baik tua ataupun muda.

Tidak banyak orang yang sadar bahwa kehidupan seseorang sangat ditentukan oleh cara berfikirnya. Apabila ia berfikir atau mempunyai gambaran sebagai orang yang penakut dan pesimis, maka gambaran tersebut akan mempengaruhi seluruh potensi dirinya yang ada sebagai seorang yang penakut. Ketakutan dan keputus asaan seseorang dalam mencari rahmat Allah adalah karena ketidak mampuan dan ketidak yakinan orang tersebut dalam menghadapi masalah tersebut. Firman Allah SWT dalam surat Al- Hijr ayat 52: Artinya: "Ketika mereka masuk ke tempatnya, lalu mereka mengucapkan: "Salaam". Berkata Ibrahim: "Sesungguhnya kami merasa takut kepadamu"."

${ }^{4}$ Sayid Qhutub,2003,Tafsir Fizhilail Qur'an,Genma Insani Press: Jakarta. hal 390 
Kata "Wajilun" terambil dari kata "Wajal" yaitu kegoncangan hati akibat menduga akan terjadi sesuatu yang buruk. ${ }^{5}$ Pantaslah Allah SWT sendiri berkata "aku menurut prasangkamu". ${ }^{6}$ Apabila kita memiliki prasangka buruk kepada Allah SWT, berarti kita menghinakan diri sendiri dan bersiap untuk menerima kebrukan tersebut.

Nilai Pendidikan yang Terkandung Di dalam Surat Yusuf ayat 87:

Sebagai peserta didik kita harus senantiasa rajin dan bersungguh-sungguh dalam menuntut ilmu dimanapun. Peserta didik dan pendidik hendaknya selalu berdoa kepada Allah dan berusaha semaksimal mungkin dalam melakukan proses belajar. Jangan pernah menyerah atau berputus asa dalam meraih cita-cita dan juga ketika mengalami kegagalan. Bagi pendidik harus senantiasa sabar, ulet dan cekatan dalam mendidik, mengajar dan membimbing siswanya. Bagi peserta didik diharuskan untuk selalu mempersiapkan segala kebutuhan yang dibutuhkan dalam proses pembelajaran.

\section{B. Terbentuknya Konsep Percaya Diri}

Terbentuknya kepribadian yang baik sesuai dengan proses perkembangan yang melahirkan kelebihan-kelebihan tertentu.

1. Pemahaman seseorang terhadap kelebihan-kelebihan yang dimilikinya dan melahirkan keyakinan yang kuat untuk bisa berbuat segala sesuatu dengan memanfaatkan kelebihan-kelebihannya.

2. Pemahaman dan reaksi positif seseorang terhadap kelemahan-kelemahan yang dimilikinya agar tidak menimbulkan rasa rendah diri atau sulit menyesuaikan diri.

3. Pengalaman didalam menjalani berbagai aspek kehidupan dengan menggunakan segala kelebihan yang ada pada diri sendiri.

Terbentuknya rasa percaya diri yang kuat terjadi melalui proses :

a. Terbentuknya kepribadian yang baik sesuai dengan proses perkembangan yang melahirkan kelebihan-kelebihan tertentu.

b. Pemahaman seseorang terhadap kelebihan-kelebihan yang dimilikinya dan melahirkan keyakinan yang kuat untuk bisa berbuat segala seuatu dengan memanfaatkan kelebihan - kelebihannya tersebut.

c. Pemahaman dan reaksi positif seseorang terhadap kelemahan-kelemahan yang dimilikinya agar tidak menimbulkan rasa rendah diri atau rasa sulit menyesuaikan diri.

\footnotetext{
${ }^{5}$ M. Quraish Sihab,2007,Tafsir Al-Misbah,Lentera Hati:Jakarta. hal 142.

${ }^{6}$ Toto Tasmara,2001,Kecerdasan Ruhaniah,Gema Insani:Jakarta. hal 88.
} 
d. Pengalaman didalam menjalani berbagai aspek kehidupan dengan menggunakan segala kelebihan yang ada pada dirinya. The experienxe is the best teacher, dari berbagai pengalaman itulah, sahabat bisa memantapkan langkah, untuk percaya diri dalam berbagai hal, coz udah ada bekalnya.

I. Faktor-faktor yang mempengaruhi terbentuknya Percaya diri

Kepercayaan diri dapat dipengaruhi oleh beberapa faktor yang dapat digolongkan menjadi dua faktor :

A. Faktor Internal, yang termasuk dalam faktor ini adalah ;

1. Konsep diri ternbentuknya kepercayaan diri pada seseorang diawali dengan perkembangan konsep diri yang diperoleh dalam pergaulan suatu kelompok. Menurut Centi (1995). Konsep diri merupakan gagasan tentang dirinya sendiri. Seseorang yang mempunyai rasa rendah diri biasanya mempunyai komsep diri negatif. Sebaliknya orang yang mempunyai konsep diri positif.

2. Harga diri meadow (dalam kusuma, 2005) harga dirin yaitu penilaian yang dilakukan terhadap diri sendiri. Orang yang mempunyai harga diri tinggi akan menilai pribadi secara rasional dan benarbagi dirinya serta mudah mengadakan hubungan dengan individu lain. Orang yang mempunyai harga diri tinggi akan menilai pribadi secara rasional dan benar-benar dirinya serta mudah mengadakan hubungan dengan individu lain. Orang yang mempunyai harga diri tinggi cenderung melihat dirinya sebagai individu yang berhasil percaya bahwa usahanya mudah menerima orang lain sebagaimana menerima dirinya sendiri. Akan tetapi orang yang mempunyai harga diri rendah bersifat tergantung, kurang percaya diri dan biasanya terbentur pada kesulitan sosial serta pesimis dalam pergaulan.

3. Kondisi fisik. perubahan kondisi fisik juga berpengaruh pada kepercayaan diri. Anthony (1992) mengatakan penampilan fisik merupakan penyebab utama rendahnya harga diri dan percaya diri seseorang. Lauster (1997) juga berpendapat bahwa ketidak mampuan fisik dapat menyebabkan rasa rendah diri yang kentara.

4. Pengalaman hidud, Lauster (1997) mengatakan bahwa kepercayaan diri diproleh dari pengalaman yang mengecewakan, yang sering menjadi sumber timbulnya rasa rendah diri. Lebih-lebih 
jika pada dasarnya seseorang memiliki rasa tidak aman, kurang kasih sayang kurang perhatian.

B. Faktor eksternal

1. Pendidikan, pendidikan mempengaruhi kepercayaan diri seseorang. Anthony (1992) lebih lanjut mengungkapkan bahwa tingkat pendidikan yang rendah cenderung membuat individu merasa dibawah kekuasaan yang lebih pandai, sebaliknya individu yang pendidikannya lebih tinggi akan cenderung mandiridan tidak perlu tergantung pada orang lain. Individiu tersebut akan memenuhi keperluan hidup dengan rasa percaya diri dan kekuatannya dengan memperhatikan situasi dari sudut kenyataan.

2. Pekerjaan Rogers (dalam kusuma, 2005) mengemukakan bahwa bekerja dapat mengembangkan kreatifitas dan kemandirian serta rasa percaya diri. Lebih lanjut dikemukakan bahwa rasa percaya diri dapat mucul dengan melakukan pekerjaan. Selain materi yang diperoleh, kepuasan dan rasa bangga didapat karena mampu mengembangkan kemampuan diri.

3. Lingkungan dan pengalaman hidup. Lingkungan disini merupakan lingkungan dan masyarakat. Dukungan yang baik yang diterima dari lingkungan keluarga seperti anggota yang sering berinteraksi dengan baik akan memberi rasa nyaman dan percaya diri yang tinggi. Begitu juga dengan lingkungan masyarakat, semakin lancar harga diri berkembang (centi, 1995). Sedangkan pembentukan kepercayaan diri juga bersumber dari pengalaman pribadi yang dialami seseorang dalam perjalanan hidupnya. Pemenuhan kebutuhan psikologis merupakan pengelaman yang buruk pada masa kanak-kanak akan menyebabkan individu kurang percaya diri (drajat, 1995).

Dalam sebuah hadist, Rasulullah SAW menjelelaskan tentang peran dan dampak seorang teman. Dalam sabda beliau: "permisalan teman yang baik dan teman yang buruk ibarat seorang penjual minyak wangi dan seorang pandai besi. Penjual minyak wangi mungkin akan memberimu minyak wangi, atau engkau bisa membeli minyak wangi darinya, dan kalaupun tidak, dan kalaupun tidak engkau tetap mendapatkan bau harum darinya. Sedangkan pandai besi, bisa jadi (percikan apinya), mengenai pakaianmu, dan 
kalaupun tidak engkau tetap mendapatkan bau asapnya yang tak sedap". (HR. Bukhari 5534 dan Muslim 2628).

\section{Kesimpulan}

Semua penjelasan mengenai tafsir dan kandungan ayat-ayat di atas sebagai sebuah dalil diperintahkannya kepada manusia untuk senantiasa percaya diri terhadap kemampuan yang dimiliki dengan diiringi do'a kepada Allah SWT dan jangan pernah berhenti berusaha atau berjuang untuk mencari rahmat Allah dalam bentuk apapun. Terutama bagi pelajar yang sedang menuntut ilmu untuk senantiasa mengamalkan kedua sifat tersebut menjadi sikap dalam keseharian. Hendaknya kita senantiasa bersikap sebagai berikut:

Selalu optimism dalam menghadapi berbagai rintangan kehidupan; Senantiasa berusaha dan berdo'a dalam segala perbuatan; Bertawakkal kepada Allah atas segala sesuatu yang terjadi; Tak pernah berhenti mengharapkan rahmat dan ridlo-Nya; Yakin akan kemampuan yang dimiliki dan didasari dengan berdo'a dalam melakukan suatu tindakan; Senantiasa bersyukur atas segala yang diberikan oleh Allah kepada kita; Mengamalkan kedua sifat tersebut dalam menuntut ilmu. Sesungguhnya agama islam memerintahkan agar berserah diri dan ikhlas kepada Allah SWT. Kita sebagai manusia agar percaya diri dan tidak putus asa untuk terus mencari rahmat Allah. Banyak manusia yang cepat putus asa bahkan melampiaskanya dengan bunuh diri, hal itu disebabkan karena pemikiranya yang dangkal dan jauh dari nilai - nilai yang terkandung dalam Al-Qur'an. Kita sebagai manusia wajib ikhtiar, karena semua masalah pasti ada jalan keluarnya.

\section{Penutup}

Pada akhirnya, konsep-konsep kepribadian yang dikemukakan oleh berbagai aliran psikologi, karena teori-teori ini berasal dari masyarakat budaya "Barat" yang diyakini sedikit banyak, berbeda dari masyarakat "Timur" ada kemungkinan teori yang mereka sampaikan terasa asing bagi masyarakat timur atau bahkan bertentangan dengan konsep-konsep Islam. Maka perlu kiranya bagi ilmuwan Muslim untuk mencari konsep-konsep tersebut dengan mengggunakan tolok ukur yang telah ditentukan oleh al-Qur'an dan Sunnah agar tidak terjebak ke dalam pemikiran yang sekuler. Dengan bertitik tolak pada konsep al-Qur'an akan dapat dipahami bagaimana ajaran Islam terhadap konsep-konsep keilmuan yang dalam hal ini adalah konsep percaya diri. optimism dalam menghadapi berbagai rintangan kehidupan; Senantiasa berusaha dan berdo'a dalam segala perbuatan; Bertawakkal kepada Allah atas segala sesuatu yang terjadi; Tak pernah berhenti mengharapkan rahmat dan ridlo-Nya; Yakin akan kemampuan yang dimiliki dan didasari dengan berdo'a dalam melakukan suatu

tindakan; Senantiasa bersyukur atas segala yang diberikan oleh Allah kepada kita; Mengamalkan kedua sifat tersebut dalam menuntut ilmu. 


\section{DAFTAR PUSTAKA}

Al Maraghi, Ahmad Mustafa. 1993. Tafsir Al-Maraghi 2. Semarang: CV Toha Mustafa

Bafadal, Fadhal AR. 2002. Al-Qur'an dan Terjemahannya juz 1-30. Surabaya: Mekar Surabaya

Dahlan, Aminah Abdul. 1985. Hadits Arba'in Annawawiyah. Bandung: PT. Al Ma'arif

Hamka. 2003. Tafsir Al-Azhar jilid 5. Singapura: Kertajaya Printing Industries

Sihab, M Quraish. 2007. Tafsir Al-Misbah. Jakarta:Lentera Hati

Tasmara, Toto. 2001. Kecerdasan Ruhaniah. Jakarta: Gema Insani 